\title{
TANÁR LESZEK, MIT GONDOLJAK?
}

\author{
NAGY KRISZTINA \\ a Kempelen Farkas Gimnázium tanára, a Pannon Egyetem \\ Nyelvtudományi Doktori Iskolájának doktorandusz hallgatója \\ kriszta.nagy@gmail.com
}

A tanárrá válás folyamata címü tanulmánygyüjtemény a szerkesztő előszavával kezdődik. Összefoglalja a tanulmányok szerzőinek írásait, véleményeiket a témában. Ezután következik Kimmel Magdolna A tanárképzés problémái konstruktivista értelmezési keretben, majd Dudás Margit Tanárjelöltek belépö nézeteinek feltárása, Köcséné Szabó Ildikó Milyen tanár leszek? - Hallgatók vallanak magukról, a tanári hivatásról, Kotschy Beáta A pedagógusok szakmai fejlödésének új perspektivái: a szakmai fejlesztő iskolák, végül Sántha Kálmán Kvalitatív módszerek alkalmazása a reflektiv gondolkodás feltárásában címü írása. Összességében elmondható, hogy a könyv minden cikke a tanárjelölteket, azok gondolkodását vizsgálja, empirikus vizsgálatok segítségével, illetve ezek eredményeit közlik.

Kimmel Magdolna írása szerint a mai egyetemi képzésben az elmélet és a gyakorlat nem fedi egymást. Az egyetemen szerzett tudással nem vagy nehezen áll helyt egy kezdő pedagógus. Azonban nem szabad azt sem elfelednünk, hogy a megfelelő tudományos oktatás nélkül alapvetően alkalmatlan lenne a pedagógusjelölt a tanári pályára. A tudományos nézőpont átadása segítséget nyújt a pályakezdő pedagógusnak, hogy megtalálja a helyét a mindennapi életben. Azonban hiába kapná meg egy hallgató a megfelelő gyakorlati oktatást tudományos nézőpontok közvetítése nélkül. Egyetértek tehát Kimmel Magdolnával, de a gyakorlati oktatás nem mehet az elméleti kárára. „A hallgatók többsége úgy kezd el tanítani, ahogyan őket tanították annak idején a közoktatás keretein belül” - írja a szerző (Kimmel, 2007, 11. o.). Felmerült a kérdés, meg lehet-e változtatni a tanárjelölt önmagában felépített tanárképét. Nehéz, de lehetséges feladat. Mindenképpen tapasztalati úton kell megszerezni az új ismereteket.

A Tanárjelöltek belépö nézeteinek feltárása címü írás is hasonló gondolkodásmódot követ. A tapasztalatok a tanárrá válás fö meghatározói, ezt Dudás Margit is megfogalmazza. „A fogalomtérkép módszer segítségével a belépő hallgatók tanári mesterségröl, a tanításról, a tanulásról és önmagukról kialakult nézeteit vizsgáltam”- írja (Dudás, 2007, 63. o.). A vizsgálatok életszerủ adatokat eredményeztek, például hogy magukról a tanárjelöltek, mint tanárokról, elvárásokat gyüjtöttek össze. Feltárta a tanárok, diákok fogalomtérképét. A tanárképben felfedezhetőek a pe- 
dagógiai kultúra hatásai, mint például, hogy szerepel vagy nem szerepel a tanárnak mint segítőnek az említése a vizsgált alanyok részéről.

Köcséné Szabó Ildikó írásában a hallgatók vallanak. A tanárról alkotott nézeteikről, a személyes tulajdonságaikról, mint például, hivatásszerüség, a pálya iránti érdeklődés, a gyerekekhez kapcsolódó érzelmi kötődés. Az előző tanulmányhoz hasonlóan ő is meghatározza az egyes kapcsolatokat az iskolában, továbbá a tanári tevékenység alapjait. A két tanulmány mintegy kiegészíti egymást, nem véletlenül kerültek egy kötetbe. Mindenképpen hasznos írás a kezdő pedagógusok számára.

Kotschy Beáta A pedagógusok szakmai fejlödésének új perspektívái: a szakmai fejlesztő iskolák címü írása a szakmai fejlesztő iskolák húszéves történetét mutatja be. Alapvetően egyetértek azzal a gondolattal, hogy a pedagógusoknak rendszeres továbbképzésre van szükségük. Ez elengedhetetlen, nagyon helyesen hívja fel rá a figyelmet. A két intézmény között együttmüködésnek kell kialakulnia. A hálózat kiépítése azonban még nem zárult le, és nem is tökéletes. Az együttmüködés emeli az oktatás színvonalát.

A kötetet Sántha Kálmán írása zárja. Gyakorló pedagógusok tevékenységét elemzi a reflektív szemlélet és gyakorlat kialakulásának szempontjából. Több pedagógust is megkérdezett, akik különböző ideje vannak a tanári pályán. Az eredmények, természetesen eltérőek, de nem meglepőek. A tapasztalat és az idő bizony különbséget eredményez. Videofelvételek, interjúk, fogalomtérképek. Ezekkel kimutatja, milyen kérdésekre, milyen mélységig hatol a pedagógusok önreflexiója.

A Falus Iván által szerkesztett könyv mindenképpen aktuális témát dolgoz fel. Olyan kérdéseket gyüjtött, melyek komolyan foglalkoztatják a tanári pályán lévőket, és az arra készülőket egyaránt. A könyvnek erénye, hogy alapos, szakszerü és olvasmányos. A téma aktualitása, a remek megfogalmazás miatt érdemes időt szentelni rá.

Falus Iván (szerk.): A tanárrá válás folyamata. Budapest, Gondolat Kiadó, 2007, 243 oldal 